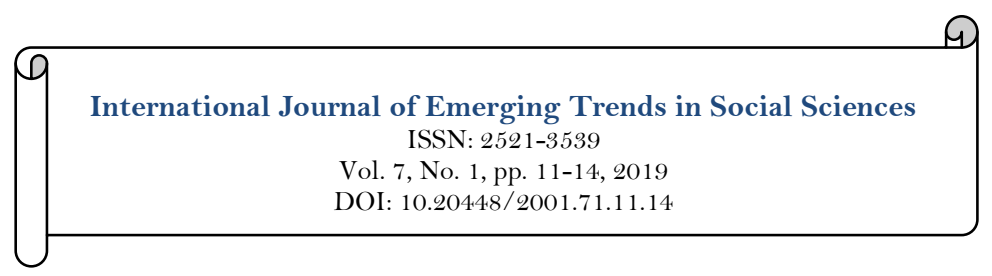

$\checkmark$ updates

\title{
Shortage of Technicians, Intellectual Property Rights Disputes and Labor Property Rights
}

\author{
Jingchao Dai ${ }^{1}$ \\ Lucong Wang ${ }^{2}$ \\ 1,2PhD Candidate, School of Economics, Central University of Finance and Economics, Beijing, China. \\ 'Email:jingchaodai2017@163.com \\ EEmail:paper2017@163.com
}

\begin{tabular}{l|l}
\multicolumn{3}{|c|}{ Abstract } & \\
This paper analyzes the shortage of technical personnel in China from the & Keywords: \\
perspective of intellectual property rights (IPR) protection and the labor & Technicians \\
property rights. From the micro point of view, this paper points out that due & Intellectual property rights \\
to the uniqueness of intellectual labor, intellectual property right system and & Disputes \\
the incomplete property rights of intellectual labor, intellectual property & Labor property rights. \\
rights disputes occur between technical personnel and enterprises. Such & \\
conflicts greatly reduce the return on human capital investment of skilled & Licensed: \\
personnel, which leads to insufficient supply of labor and shortage of skilled & This work is licensed under a \\
workeative Commons Attribution 4.0 \\
disputes of intellectual property rights and the shortage of technical \\
personnel.
\end{tabular}

Funding: This study received no specific financial support.

Competing Interests: The authors declare that they have no competing interests.

\section{Introduction}

According to the related data from the Ministry of Human Resources and Social Security in China, in 2017 China has 170 million skilled workers, accounting for 20 percent of the total employment, of which about 50 million are highly skilled technicians, accounting for far less than 10 percent of the total employment. China's shortage of technical personnel is increasingly prominent. Lack of emphasis on vocational education, unreasonable course structure, problems in internal incentive of high-skilled technical personnel, etc., may lead to shortage of technicians.

This paper analyzes the shortage problem from the perspective of intellectual property rights (IPR) protection and the labor property rights. Due to the uniqueness of intellectual labor, intellectual property right system and the incomplete labor property rights, intellectual property rights disputes always occur between technical personnel and enterprises. Such conflicts are not conducive to motivating technicians, which will lead to the shortage of technicians. So this kind of disputes need to be resolved if the supply of technicians want to be increased. Firstly, this paper introduces the forms of intellectual property disputes between technicians and enterprises. Then explain the causes of such disputes, and throw light on the relationship of shortage of technicians, IPR disputes and incomplete labor property rights. Finally put forward solutions.

\section{The Forms of IPR Disputes between Technicians and Enterprises}

For the protection and confidentiality of intellectual property rights, when an enterprise signs a labor contract with an intellectual worker, it usually agrees on the confidentiality of intellectual property rights or the terms of competition restriction in accordance with the Labor Contract Law, Patent Law or others. If the intellectual worker completes the task assigned by the enterprise or his intellectual achievement is 
accomplished by using the material conditions, technical conditions or personnel conditions of the enterprise, then the intellectual property right shall be attributed to the enterprise as a service invention, and the enterprise shall be the patentee. An individual intellectual worker may also apply for a patent together with the enterprise as a second applicant. If the ownership of patent right is not clearly agreed, the intellectual property right may belong to the individual intellectual worker. At the same time, knowledge workers are entitled to rewards for service invention. After the intellectual workers sign the non-competition agreement, the enterprise shall give economic compensation to the intellectual workers within the period of limitation of competition. Of course, if knowledge workers violate the agreement, also should pay liquidated damages.

Although relevant laws have provisions and restrictions on all aspects of intellectual property rights, disputes still occur between technical personnel and enterprises in the process of work practice. For example, the ownership disputes of whether the intellectual property rights belong to the service invention of enterprises or to the knowledge workers who have completed the creation; the trade secret disputes of whether a knowledge worker divulges technical secrets and do damage to the interest of enterprises; the money disputes of whether an enterprise should pay a bonus for a service invention to a knowledge worker or whether the amount of the bonus is appropriate; disputes over whether an employee is working for a competitor in a related industry violating the non-competition agreement.

\section{The Reasons of IPR Disputes between Technicians and Enterprises}

The uniqueness of knowledge labor determines the particularity of disputes between enterprises and technical personnel. Firstly, a very obvious difference between intellectual labor and pure physical labor is that physical labor is explicit and can be seen or felt by people. But the knowledge labor is different, it exists in the knowledge worker's mind. The process of knowledge creation by knowledge workers is the process of learning and thinking, which is not restricted by time and place and other objective external conditions. That is to say, although knowledge workers are engaged in seemingly easy and free work, they may spend all their time in knowledge labor for invention and creation, not just in the workplace during working hours. This virtually lengthens the working time. Secondly, in the era of knowledge economy, the criterion for measuring the achievements of knowledge labor is results-oriented rather than process-oriented. Knowledge workers may not gain anything after they spend a lot of time and effort on hard intellectual labor. And just because the focus is on the result, the performance appraisal standards established by enterprises to supervise knowledge workers will further increase the burden and pressure on knowledge workers, forcing them to pay more efforts in $\mathrm{R} \& \mathrm{D}$ and creation. Thirdly, spiritual wealth, unlike material wealth, is hard to measure. The product of labor created by knowledge worker is a kind of spiritual wealth, so there is no specific standard to measure its value. Whether the labor remuneration that the knowledge worker gets from the enterprise matches with the labor value he pays cannot be effectively measured, or the measured cost is very large.

Table-1. Proportion of the number of service patent applications accepted

\begin{tabular}{|c|c|c|c|c|c|c|}
\hline \multirow[b]{2}{*}{ Year } & \multicolumn{2}{|c|}{ Patent for invention } & \multicolumn{2}{|c|}{ Utility model patent } & \multicolumn{2}{|c|}{ Design patent } \\
\hline & $\begin{array}{c}\text { Domestic } \\
\text { service patent }\end{array}$ & $\begin{array}{c}\text { Foreign service } \\
\text { patent }\end{array}$ & $\begin{array}{c}\text { Domestic } \\
\text { service patent }\end{array}$ & $\begin{array}{c}\text { Foreign } \\
\text { service } \\
\text { patent }\end{array}$ & $\begin{array}{c}\text { Domestic } \\
\text { service } \\
\text { patent }\end{array}$ & $\begin{array}{c}\text { Foreign } \\
\text { service } \\
\text { patent }\end{array}$ \\
\hline 2017 & $83.79 \%$ & $97.79 \%$ & $80.28 \%$ & $92.45 \%$ & $55.64 \%$ & $94.72 \%$ \\
\hline 2016 & $81.58 \%$ & $97.89 \%$ & $77.37 \%$ & $91.29 \%$ & $51.53 \%$ & $93.76 \%$ \\
\hline 2015 & $80.16 \%$ & $97.92 \%$ & $76.69 \%$ & $93.13 \%$ & $48.64 \%$ & $94.65 \%$ \\
\hline 2014 & $80.89 \%$ & $97.89 \%$ & $75.94 \%$ & $93.66 \%$ & $49.44 \%$ & $94.15 \%$ \\
\hline 2013 & $81.01 \%$ & $97.88 \%$ & $71.56 \%$ & $93.41 \%$ & $54.40 \%$ & $94.22 \%$ \\
\hline 2012 & $80.03 \%$ & $97.65 \%$ & $69.74 \%$ & $93.66 \%$ & $54.90 \%$ & $95.22 \%$ \\
\hline 2011 & $77.97 \%$ & $97.57 \%$ & $66.68 \%$ & $90.59 \%$ & $49.36 \%$ & $95.59 \%$ \\
\hline 2010 & $76.35 \%$ & $97.36 \%$ & $59.54 \%$ & $86.53 \%$ & $47.01 \%$ & $94.95 \%$ \\
\hline 2009 & $75.16 \%$ & $96.69 \%$ & $54.85 \%$ & $84.40 \%$ & $41.65 \%$ & $93.87 \%$ \\
\hline 2008 & $72.18 \%$ & $97.45 \%$ & $47.83 \%$ & $81.11 \%$ & $39.12 \%$ & $96.44 \%$ \\
\hline 2007 & $70.34 \%$ & $97.32 \%$ & $41.51 \%$ & $75.62 \%$ & $36.98 \%$ & $96.61 \%$ \\
\hline 2006 & $66.62 \%$ & $97.35 \%$ & $36.73 \%$ & $78.67 \%$ & $33.67 \%$ & $95.50 \%$ \\
\hline 2005 & $66.61 \%$ & $97.16 \%$ & $33.95 \%$ & $79.07 \%$ & $32.81 \%$ & $95.30 \%$ \\
\hline 2004 & $63.46 \%$ & $96.53 \%$ & $31.56 \%$ & $81.80 \%$ & $33.78 \%$ & $96.05 \%$ \\
\hline 2003 & $61.18 \%$ & $96.32 \%$ & $31.57 \%$ & $84.52 \%$ & $38.88 \%$ & $96.84 \%$ \\
\hline
\end{tabular}

In addition, when signing labor contracts, intellectual workers are often required to attribute intellectual property created during their employment to the enterprise, or sign non-competition agreements. As shown in Table 1 among all kinds of patent applications accepted in China, the proportion of service patents exceeds 
$50 \%$. In addition, with the exception of the domestic service patent for design, the proportion of the acceptance of other service patent applications is above $80 \%$, while the proportion of the acceptance of foreign service patent applications is above $90 \%$, and the proportion of foreign service invention patents is even as high as $98 \%$.

Although knowledge workers will be compensated or rewarded, their enthusiasm for knowledge creation will be somewhat frustrated. In addition, the creativity of knowledge labor is a process of continuous accumulation. With the increase of the working years of knowledge workers, their knowledge creation ability is increasing day by day, but the increase rate of labor remuneration and the renewal rate of labor contracts is often not as fast as the appreciation rate of value created by knowledge workers. Therefore intellectual property rights disputes occur frequently and are widely concerned.

\section{The Relationship of Shortage of Technicians, IPR Disputes and Labor Property Rights}

As for the essence of the dispute between technical personnel and enterprises, it can be explained by the fact that the intellectual property rights system aggravates the incomplete property rights of skilled personnel's intellectual labor force. The labor force has the character of commodity, also have the attribute of property right. The concept of the property right of labor force is relative to the property right of material capital. It refers to the property rights owned by the employee who is employed to work. Therefore, as the subject of labor force, the property right of labor force should meet the living needs of laborers, namely the right to subsistence and development. At the same time, satisfy the right of laborers to produce or reproduce, and the right to independently control their labor force. And the property right of labor force should satisfy the right of laborers to participate in labor to obtain additional income distribution. However, the laborer cannot own all the property right of the labor force. The ownership of labor property rights is separated from the right to use and control (Zhang., 2013).

With the further dependence of the productive forces on science and technology, science and technology have become the primary productive forces, and knowledge has become the main driving force to improve the productive forces and the main source of creating social wealth. The salaries, working environment, living standards and other aspects of intellectual workers have been greatly improved. However, without the material conditions such as research and development equipment, it is difficult for knowledge workers to integrate knowledge into the production process and turn it into tangible commodities. Pure knowledge produces nothing and plays no role. Therefore, enterprises employ knowledge workers by paying labor remuneration, and supervise, manage and assess knowledge workers to perform their duties for R\&D design in accordance with the labor contract. The strict intellectual property rights system will make the intellectual workers, because they are employed by enterprises, unable to use the knowledge products they create freely, or disclose the specific content and process of research and development to the outside world, and unable to obtain the additional benefits brought by the knowledge products in addition to the salary or reward for invention. Although in modern enterprises, there have been incentive policies for knowledge workers to hold company shares with knowledge technology or information. However, the majority of technical personnel still cannot take advantage of the additional benefits of knowledge labor force on knowledge products. Or even with the added benefit of knowledge products, the share of technical people is small.

In addition, intellectual labor has the attribute of legal right, which is not only affected by the intellectual property protection system, but also affected by other laws. For example, the Company Law, Property Law and other laws protecting material capital provide comprehensive provisions and protection for all aspects of the bundle of material capital property rights. As a law to protect the property rights of labor, the Labor and Social Security Law guarantees the right of ownership, the right to use and dispose of the labor property rights, and the right to obtain wage remuneration in the right of income (Chen, 2010; Lai \& Yao, 2011). Therefore, in terms of the scope and intensity of legal protection, the degree to which the property rights of labor and the property rights of material capital are protected is inconsistent and unequal. To be specific, the Company Law stipulates that shareholders have the residual claim of the enterprise, but only the owner of the material capital can contribute to the investment. Even in a partnership firm, labor force can be a shareholder but is more restricted. That is to say, it is stipulated on the legal level that all or most of the residual claim belongs to the owner of material capital instead of the laborer. At the same time, the rights to manage enterprises or make major decisions are also in the hands of the owners of material capital, and it is not easy to have a place for knowledge workers. Therefore, no matter because the intellectual property protection system intensifies the disparity between the strength of enterprises and intellectual workers, or because other laws restrict the rights enjoyed by workers to the property rights of labor, intellectual workers are unable to strive for the additional benefits of their intellectual labor (Nian \& Hu, 2010).

Intellectual workers can not enjoy the complete right bundle of the labor force property rights. And with the more and more income brought by intellectual labor products, Intellectual property disputes continue. In China's economic environment, especially for private enterprises, foreign-funded enterprises and other mixedownership enterprises, disputes between technical personnel and enterprises are caused by the different economic interest demands and distribution need of intellectual worker and the owner of material capital. It is the Income distribution relationship of unity of opposites between intellectual labor property and material 
capital property. Whether the labor property right of technical personnel is complete is one of the main factors that determine the scale of talent supply. The unfair and unbalanced distribution of the interests of intellectual property rights and the incomplete property rights greatly reduce the returns brought by the human capital investment of technical personnel. Resulting in a lack of investment, leading to a shortage of skilled workers.

\section{The Solution of IPR Disputes and Shortage of Technicians}

The key to solve the disputes between technical personnel and enterprises is to pay more attention to the rights and benefits enjoyed by intellectual workers in enterprises. So that technical personnel can not only obtain salaries, but also can obtain profits. Therefore, for technical personnel, it is necessary to ensure that they can reasonably and legally share the additional benefits brought by knowledge products. On the one hand, the interests of technical personnel and the interests of enterprises can be bound together, so as to effectively encourage technical personnel to fully tap their own creative potential. On the other hand, the interests of technical personnel and the interests of the owners of material capital can be tied together, so as to alleviate the rights disputes, but also to benefit both sides.

It is a good method to distribute the benefits of knowledge labor between the knowledge worker and the owner of material capital. For example, the application for intellectual property rights protection should more reflects the contribution of technical personnel in the process of knowledge creation. Therefore, the intellectual property system not only protects the new knowledge, new technology and new information created in the production process, but also protects the labor paid by technical personnel to create knowledge products. For their own creation of knowledge products, technical personnel can enjoy the right to use, to control and to profit. In other words, the intellectual property system protects not only the economic interests of the owners of material capital, but also the spiritual rights and interests of intellectual workers. There are other approaches, such as the demutualization of intellectual labor rights and the system of stock futures for intellectual workers, which would effectively alleviate intellectual property disputes and increase the supply of technical personnel (Liang \& Wu, 2012; Zhang \& Yu, 2010).

\section{References}

Chen, W. B. (2010). Labor conflicts in Chinese enterprises from the perspective of human capital property rights. Economic Forum, 4, 98-101.

Lai, P. Q., \& Yao, X. G. (2011). Reconsidering the problem of labor status: A viewpoint of property strength of human capital. Academic Monthly, 43(3), 73-80.

Liang, H., \& Wu, J. (2012). Research on labor relations under dual property rights system based on the impact of human capital on labor relations. Business Times, 18, 98-100.

Nian, Z. Y., \& Hu, J. L. (2010). Research on the characteristics of corporate labor relations from the perspective of property rights. Social Science Front, 11, 244-247.

Zhang, Q. H., \& Yu, G. L. (2010). Evolution of property right theory in labor relations. Journal of Nanjing Agricultural University (Social Science Edition), 10(2), 47-53.

Zhang., F. (2013). Marx's thought of incomplete property rights of labor force and the coordination of labor-capital relations. Modern Economic Research, 10, 35-39. 